\title{
The Fabrication of ZnO Microrods on Monolayer Graphene and Their Photocatalytic Application
}

\author{
Jincheng Fan, ${ }^{1,2}$ Tengfei Li, ${ }^{2}$ Hang Heng, ${ }^{3,4}$ Berislav Marković, ${ }^{5}$ and Igor Djerdj ${ }^{1} *$ \\ ${ }^{1}$ Ruđer Bošković Institute, Bijenička 54, 10000 Zagreb, Croatia \\ ${ }^{2}$ School of Materials Science and Engineering, Anhui University of Technology, Maanshan 243002, China \\ ${ }^{3}$ Center for Analysis and Testing, Nanjing Normal University, Nanjing 210097, China \\ ${ }^{4}$ Department of Physics, Nanjing Normal University, Nanjing 210097, China \\ ${ }^{5}$ Department of Chemistry, University of Osijek, Cara Hadrijana 8A, HR-31000 Osijek, Croatia. \\ * Corresponding author: E-mail: igor.djerdj@irb.hr; \\ Tel: +38514680113; Fax: +38514680114.
}

Received: 04-05-2015

\begin{abstract}
Zinc oxide $(\mathrm{ZnO})$ microrods were fabricated on graphene/ $\mathrm{SiO}_{2} / \mathrm{Si}$ substrate by a simple hydrothermal route. The obtained products were characterized using X-ray powder diffraction, scanning electron microscopy, energy dispersive X-ray spectrometry, photoluminescence and UV-visible spectrometry. Microrods exhibits hexagonal wurzite structure. Some $\mathrm{ZnO}$ clusters and twinned $\mathrm{ZnO}$ structures were found to spread on the microrod array layer. The formation mechanism of $\mathrm{ZnO}$ microrods is discussed, emphasizing the formation mechanism of isolated clusters and twinned $\mathrm{ZnO}$ structures. Furthermore, microrods demonstrated a good photocatalytic performance towards rhodamine B degradation as ascribed to oxygen vacancies and interstitials considered as the photocatalytical active sites.
\end{abstract}

Keywords: ZnO microrods; Monolayer graphene; Photocatalytic application

\section{Introduction}

As a new discovery in materials science, graphene has attracted tremendous attention due to its extraordinary electrical, mechanical, chemical and thermal properties. ${ }^{1-4}$ It is considered to be promising material for future electronic and optoelectronic applications. ${ }^{5-7}$ However, multifunctionality of graphene is limited when integrated into devices, because it consists of only elemental carbon. To realize the full potential of graphene in advanced electronics and optoelectronics, graphene-based hybrid onedimensional nanostructures have been developed, such as $\mathrm{GaN}$ nanowire/graphene, $\mathrm{In}_{\mathrm{x}} \mathrm{Ga}_{1-\mathrm{x}}$ As nanowire/graphene, GaAs nanowire/graphene and $\mathrm{ZnO}$ nanowire/graphene. ${ }^{8-11}$ Among all graphene based hybrid nanostructures, graphene- $\mathrm{ZnO}$ nanostructures have shown superior physical and chemical properties, which can result in their application for semiconductor devices, like solar cells, gas sensors, and transparent electrodes. ${ }^{12-15}$ Zinc oxide nano- structures on graphene can be fabricated either by vapourphase or liquid-phase methods. ${ }^{16-19}$ Generally, for the former method, it is necessary to solve the problems caused by high temperature and a presence of oxygen atoms. Such conditions may result in oxidation or etching of graphene when $\mathrm{ZnO}$ nanostructures are created. On the other hand, liquid-phase method is advantageous for obtaining the $\mathrm{ZnO}$ nanostructures on graphene due to its simplicity, low cost, and low processing temperature. Kim et al. fabricated $\mathrm{ZnO}$ nanostructures on few-layer graphene sheets. They investigated the optical properties of crystallized nanorods, indicating their high optical quality. ${ }^{19}$ Hybrid $\mathrm{ZnO}$ nanorods/graphene architectures were reported elsewhere as a high-sensitive flexible gas sensors. ${ }^{11}$ Such gas sensors enabled detection of ppm ethanol vapour levels with very high sensitivity (as high as $\sim 9$ for 10 $\mathrm{ppm})$. Hwang et al. described vertical $\mathrm{ZnO}$ nanowires/graphene hybrids prepared by hydrothermal method and this hybrid architecture demonstrated excellent field 
emission properties. Very low turn-on field values of 2.0

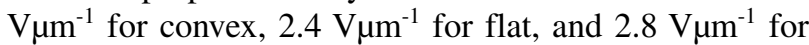
concave deformations were given. ${ }^{20}$ Excellent mechanical properties of graphene (flexibility and structural stability) indicate the promising application of $\mathrm{ZnO}$ nanorod/graphene hybrid structures for flexible electronic and optoelectronic devices. ${ }^{21}$

In this study, the preparation of zinc oxide microrods on graphene $/ \mathrm{SiO}_{2} / \mathrm{Si}$ substrate by a hydrothermal method and their photocatalytic activity is reported. Their crystal structure and optical properties were determined and the formation mechanism is discussed. $\mathrm{ZnO}$ microrods demonstrated four emissions in photoluminescence spectrum, where the green and orange emissions were assigned to $\mathrm{O}$ vacancies and $\mathrm{O}$ interstitial defects. Additionally, the photocatalytic performance of $\mathrm{ZnOmicrorods/graphene} \mathrm{was} \mathrm{investigated,} \mathrm{and} \mathrm{it} \mathrm{verified}$ the superior photocatalytic activity for the dye degradation. Again, oxygen vacancies and interstitials were considered to be the active sites of the $\mathrm{ZnO}$ photocatalyst.

\section{Experimental}

\section{1. Synthesis of $\mathrm{ZnO}$ Seeds}

To prepare the $\mathrm{ZnO}$ seeds, $2.9 \mathrm{~g}$ of zinc acetate, $\mathrm{Zn}\left(\mathrm{CH}_{3} \mathrm{COO}\right)_{2}$ was added into $62.5 \mathrm{ml}$ of methanol, $\mathrm{CH}_{3} \mathrm{OH}$ at $60{ }^{\circ} \mathrm{C}$ under vigorous stirring, dropping 32.5 $\mathrm{ml}$ solution containing $1.2 \mathrm{~g}$ of $\mathrm{NaOH}$. The obtained solution was heated and stirred at $60{ }^{\circ} \mathrm{C}$ for $3 \mathrm{~h}$, and then cooled to a room temperature. Finally, white zinc oxide precipitate was collected as a seeds for the fabrication of $\mathrm{ZnO}$ microrods. The seeds were $\mathrm{ZnO}$ nanoparticles with the diameter of $\sim 20 \mathrm{~nm}$ (Figure1).

\section{2. Fabrication of $\mathrm{ZnO}$ Microrods}

Zinc oxide microrods were prepared on graphene/Si$\mathrm{O}_{2}(300 \mathrm{~nm}) / \mathrm{Si}$ substrate by hydrothermal method. The experimental procedure comprises the following steps:

1. Graphene $/ \mathrm{SiO}_{2} / \mathrm{Si}$ substrate was cleaned in acetone, ethanol and deionized (DI) water, and dried in the air;

2. The cleaned substrate was coated with white $\mathrm{ZnO}$

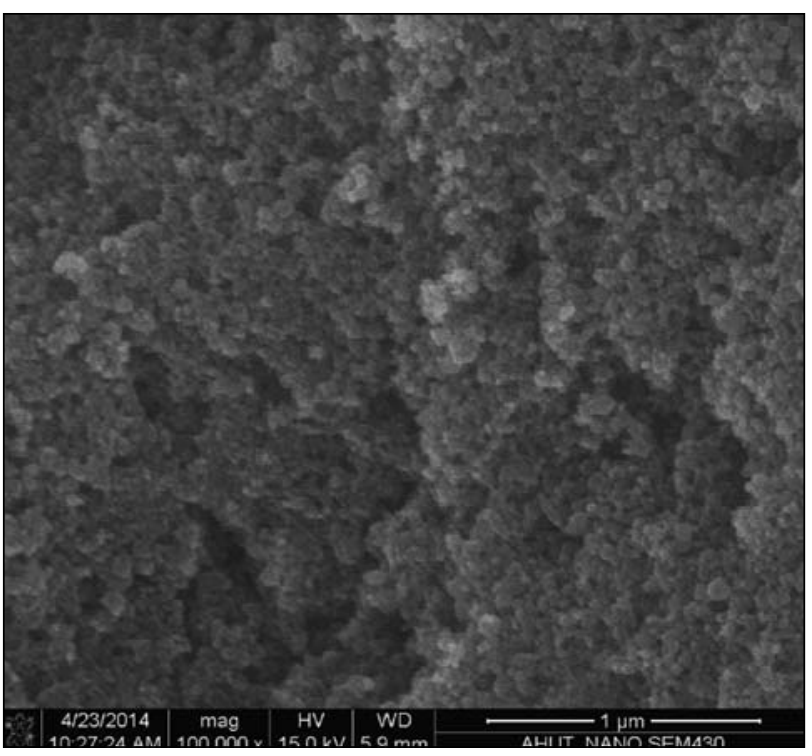

Fig. 1. SEM image of $\mathrm{ZnO}$ seeds.

precipitate prepared earlier by dropping. After dropping, the coated substrate was washed in DI water, then, dried in air;

3 . The coated substrate was rinsed in acetone, ethanol and DI water to remove the organic residue ( $\mathrm{ZnO}$ seeds remained on the graphene $/ \mathrm{SiO}_{2} / \mathrm{Si}$ substrate);

4. $200 \mathrm{ml}$ reaction solution was prepared with 14.85 $\mathrm{g}$ of zinc nitrate, $\mathrm{Zn}\left(\mathrm{NO}_{3}\right)_{2} \cdot 6 \mathrm{H}_{2} \mathrm{O}$ and $7 \mathrm{~g}$ of hexamethylenetetramine, $\mathrm{C}_{6} \mathrm{H}_{12} \mathrm{~N}_{4}$ in DI water.

5. Two seeded substrates were put into the two reactors containing the reaction solution (about 50 $\mathrm{ml})$;

6. The reactors were kept in an oven at $105^{\circ} \mathrm{C}$, one for 60 and the other for 80 minutes;

7. The reactors were cooled to a room temperature and substrates were washed with DI water and dried in the air.

The process is schematically shown in Figure 2.

Graphene used in the study was grown by chemical vapour deposition according to the procedure given in Ref.22. Graphene was prepared on $20 \mu \mathrm{m}$ thick $\mathrm{Cu}$ foil at $1000{ }^{\circ} \mathrm{C}$ with $\mathrm{CH}_{4}$ as $\mathrm{C}$ resource. After CVD growth,
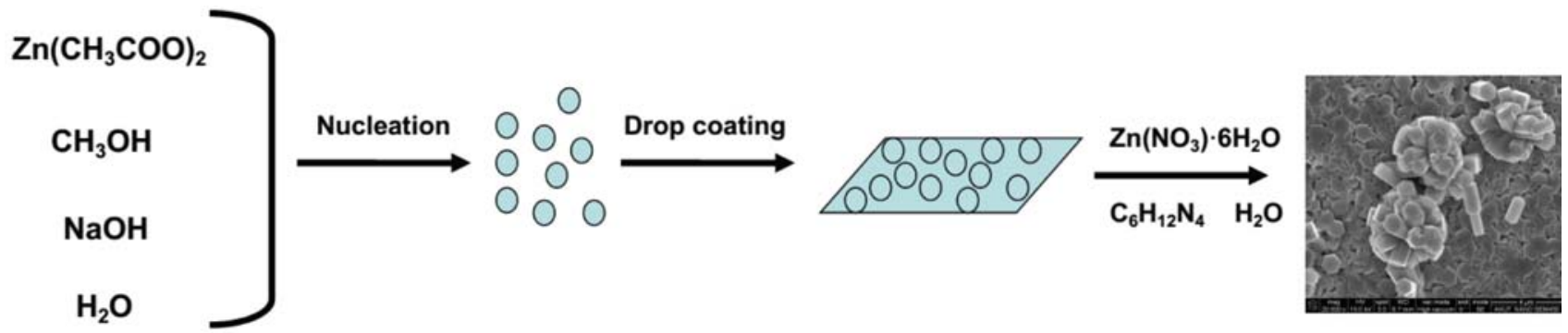

Fig. 2. Schematic process for fabricating $\mathrm{ZnO}$ micorods. 
graphene-coated $\mathrm{Cu}$ foil was covered with spin-coated Polymethyl methacrylate (PMMA) layer. $\mathrm{Cu}$ foil was etched in an aqueous solution of concentrated sulfuric acid and $\mathrm{H}_{2} \mathrm{O}_{2}$. Then, PMMA/graphene was cleaned with DI water and transferred on $\mathrm{SiO}_{2} / \mathrm{Si}$ substrate. PMMA was removed by Acetone and graphene was remained on Si$\mathrm{O}_{2} / \mathrm{Si}$ substrate. The detail can be found in experiment part of Reference22.

\section{3. Characterization}

The X-ray diffraction patterns of the samples were collected on a Bruker D8 Advance X-ray diffractometer with $\mathrm{Cu} \mathrm{K} \alpha$ radiation in the $2 \theta$ range of $25-80^{\circ}$. The morphology of the samples was examined by scanning electron microscopy (SEM, FIT Nano 430) and chemical composition determined by energy dispersive $\mathrm{x}$-ray spectrometry (EDS, Oxford Institute). UV-Vis spectra were recorded on a Shimadu UV-3660 spectrometer, and Photoluminescence (PL) spectra were measured with the 325 $\mathrm{nm} \mathrm{He}-\mathrm{Cd}$ laser as excitation source (LABRAM 800). The photocatalytic activity of the samples was evaluated using aqueous solution of $\mathrm{RhB}$ under the UV light illumination. Samples ( $\mathrm{ZnO}$ microrods/graphene/ $/ \mathrm{SiO}_{2} / \mathrm{Si}, 1.5$ $\mathrm{cm} \times 1.5 \mathrm{~cm}$ ) were immersed in $25 \mathrm{ml}$ of $\mathrm{RhB}$ solution $(5 \mathrm{mg} / \mathrm{L})$ and a $50 \mathrm{~W}$ UV lamp was used as light source. At 1 hour intervals, $2.5 \mathrm{~mL}$ of the reaction solution was collected and analysized by UV-Vis spectroscopy measuring the absorption band at $555 \mathrm{~nm}$. The degradation efficiency was evaluated by the equation: $\eta=\left(1-C / C_{0}\right)$, where $C$ and $\mathrm{C}_{0}$ were the concentrations of $\mathrm{RhB}$ after and before UV irradiation, respectively. $C / \mathrm{C}_{0}$ was calculated by $\mathrm{A} / \mathrm{A}_{0}$, because the concentration of $\mathrm{RhB}$ was linear proportion to absorption (A).

\section{Results and Discussion}

$\mathrm{D}, \mathrm{G}$ and $2 \mathrm{D}$ peaks in raman spectrum of graphene are often observed, G peak $\left(\sim 1580 \mathrm{~cm}^{-1}\right)$ is due to the bond stretching of all pairs of $\mathrm{sp}^{2}$ atoms in both rings and chains, D peak $\left(\sim 1350 \mathrm{~cm}^{-1}\right)$ is due to the breathing modes of $\mathrm{sp}^{2}$ atoms in rings and 2D peak $\left(2700 \mathrm{~cm}^{-1}\right)$ origins from two phonons with opposite momentum in the highest optical branch near the K. ${ }^{23}$

In our study, the Raman spectrum of graphene on $\mathrm{Si}$ $\mathrm{O}_{2} / \mathrm{Si}$ is shown in Fig. 3a. The two most intense features are the G peak at $\sim 1595 \mathrm{~cm}^{-1}$ and 2D peak at $\sim 2694 \mathrm{~cm}^{-1}$, indicating the well-crystallized graphitic carbon in graphene. ${ }^{23}$ Furthermore, a stronger intensity of the $2 \mathrm{D}$ peak in comparison to the $\mathrm{G}$ peak, indicates the monolayer of graphene on $\mathrm{SiO}_{2} / \mathrm{Si}$. The $\mathrm{D}$ peak, attributed to defects in graphene was also observed, but its very low relative intensity indicates the high quality of graphene. As shown in optical microscopy (OM) picture (Fig. 3b), graphene exhibited the wrinkle-free and smooth surface over a large
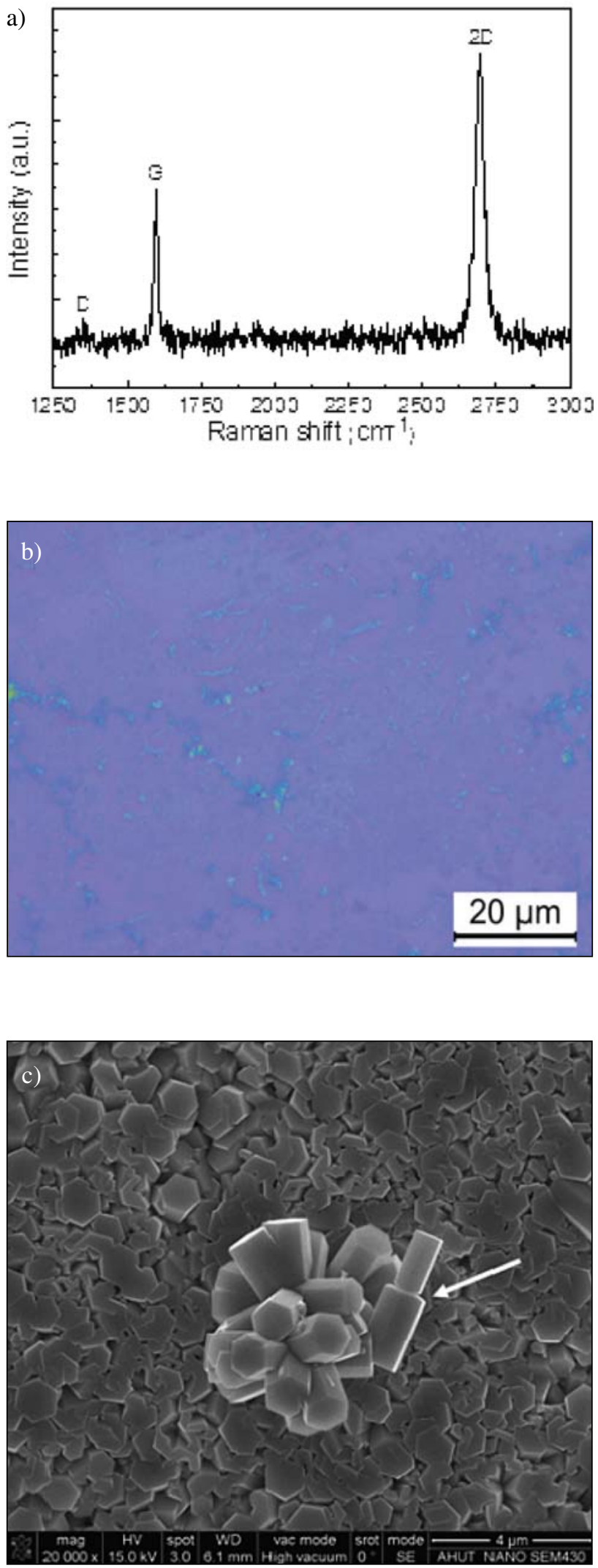

Fig. 3. (a) Raman spectrum of monolayer graphene, (b) OM image of monolayer graphene on $\mathrm{SiO}_{2} / \mathrm{Si}$; (c) The typical SEM images of $\mathrm{ZnO}$ microrods grown on monolayer graphene by the hydrothermal method. 
area, confirming its high quality. Fig. 3c illustrates SEM image of $\mathrm{ZnO}$ microrods fabricated on graphene $/ \mathrm{SiO}_{2} / \mathrm{Si}$ substrate. Obviously, the highly dense $\mathrm{ZnO}$ microrod array was formed, and the cluster and twinned $\mathrm{ZnO}$ structures were grown on such layer. The clusters are composed of microrods with very smooth surfaces that extend radially from the centre. The twinned $\mathrm{ZnO}$ structures were also observed, as marked by the white arrow in Fig.3c. Two hexagonal microrods are here connected by a common basal plane.

Scanning electron microscopy (SEM) was used to investigate the details of $\mathrm{ZnO}$ microrod structure. Figs.4a and $4 \mathrm{~b}$ show the zinc oxide microrods grown on graphe$\mathrm{ne} / \mathrm{SiO}_{2} / \mathrm{Si}$ at the same temperature but with different
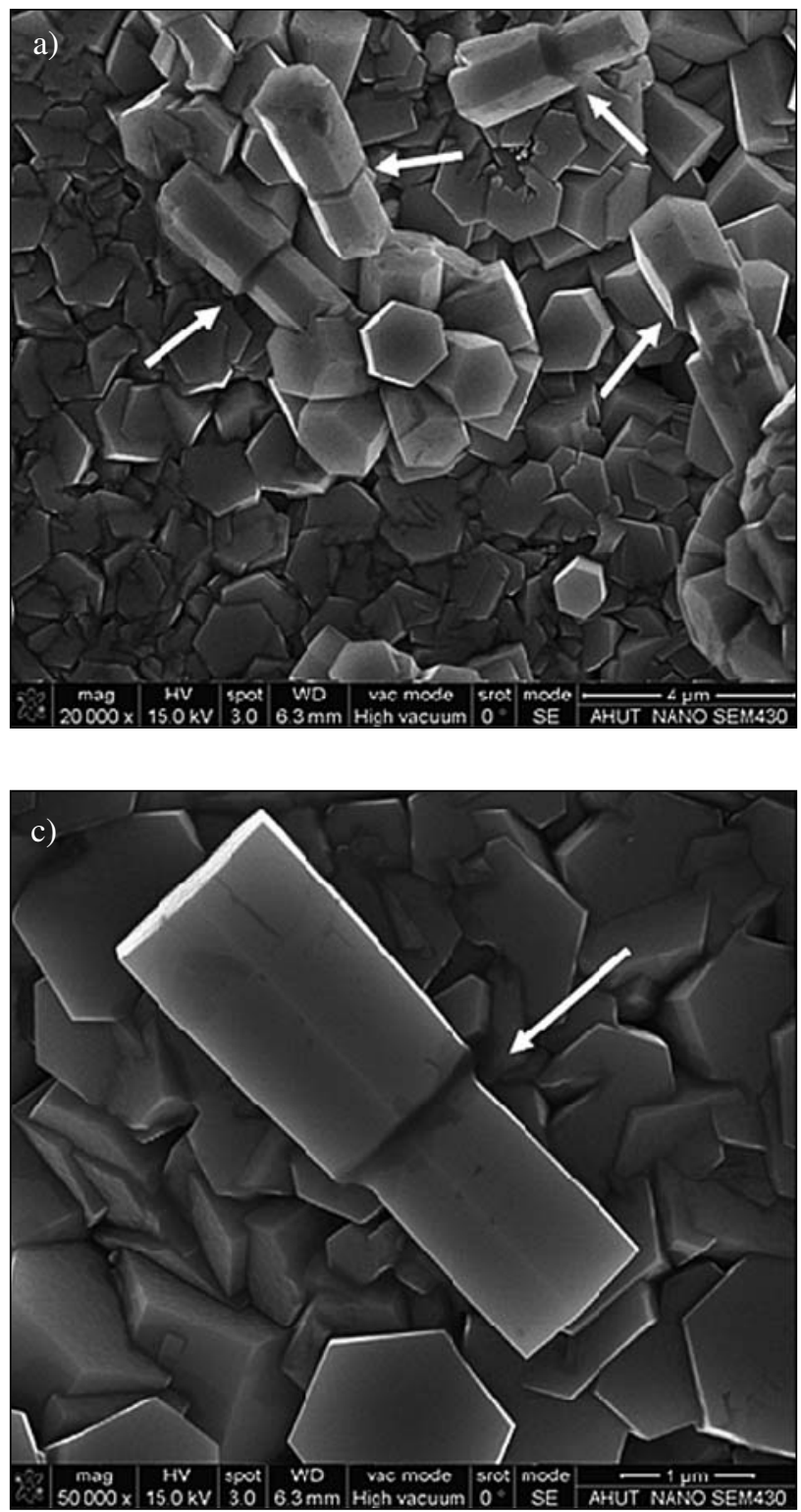

growth times -60 and 80 minutes. It can been seen, that some clusters and twinned structures are formed on the uniform microrod layer. The microrods within such clusters and twinned structures are from 0.6 to $3.5 \mu \mathrm{m}$ long and from 0.2 to $2.1 \mu \mathrm{m}$ wide. Their shape is clearly hexagonal. Figs.4c and $4 \mathrm{~d}$ show the typical twinned $\mathrm{ZnO}$ structure and the surface of a dense microrod layer.

The growth process of $\mathrm{ZnO}$ microrods in the liquid phase could be attributed to the initial precipitation of the $\mathrm{Zn}(\mathrm{OH})_{2}$ and described as follows: ${ }^{24-26}$

$$
\begin{aligned}
& \mathrm{Zn}^{2+}+2 \mathrm{OH}^{-}=\mathrm{Zn}(\mathrm{OH})_{2} \downarrow \\
& \mathrm{Zn}(\mathrm{OH})_{2}+2 \mathrm{OH}^{-}=\mathrm{Zn}(\mathrm{OH})_{4}{ }^{2-}
\end{aligned}
$$
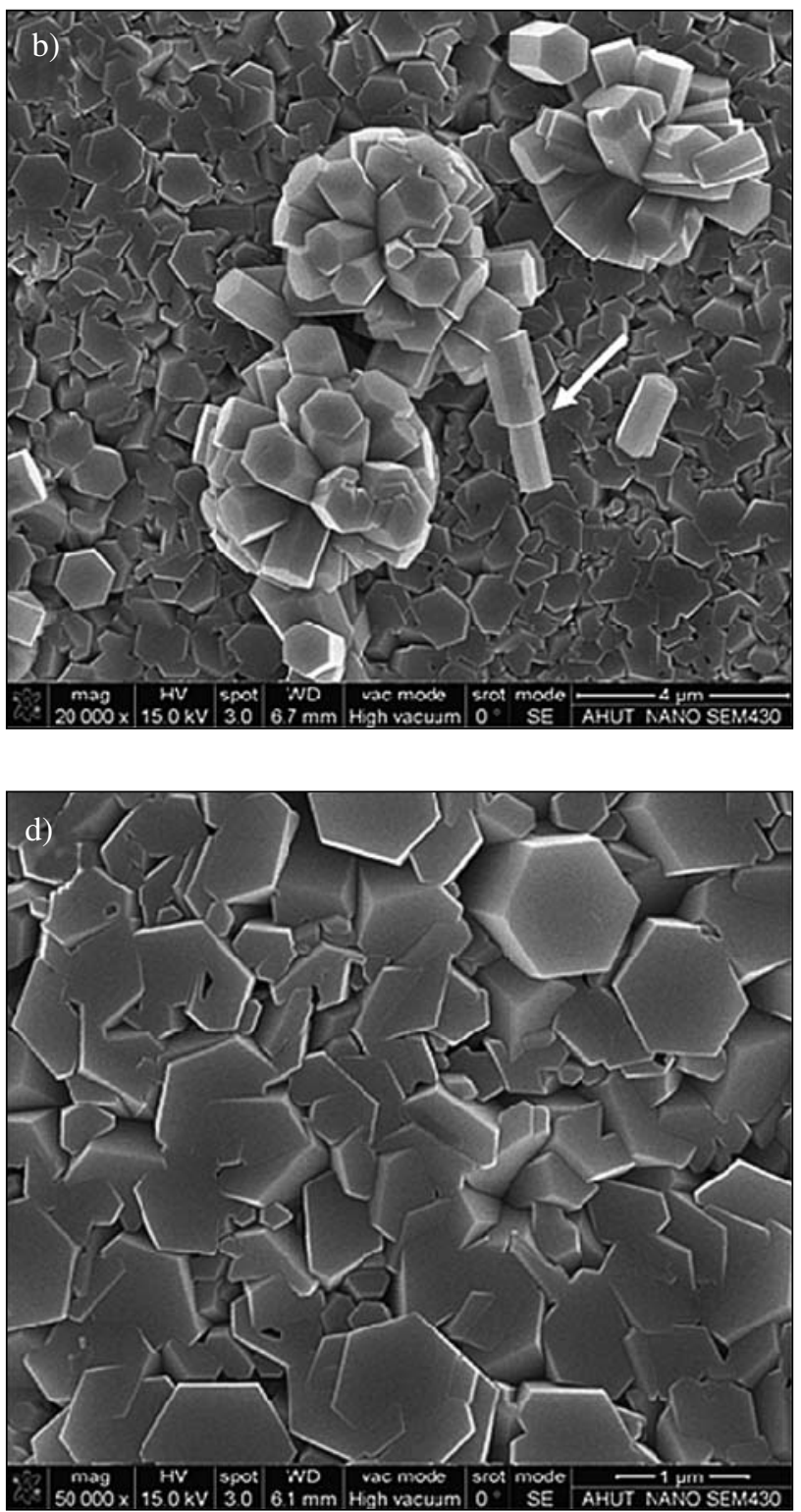

Fig. 4. SEM images of (a) $\mathrm{ZnO}$ microrods grown at $105^{\circ} \mathrm{C}$ and $60 \mathrm{~min}$. (b) $\mathrm{ZnO}$ microrods grown at $105^{\circ} \mathrm{C}$ and 80 min. (c) The typical twinned $\mathrm{ZnO}$ structure, and (d) the dense $\mathrm{ZnO}$ microrod arrays. 


$$
\mathrm{Zn}(\mathrm{OH})_{4}{ }^{2-}=\mathrm{ZnO}+\mathrm{H}_{2} \mathrm{O}+2 \mathrm{OH}^{-}
$$

Initially formed, amphoteric $\mathrm{Zn}(\mathrm{OH})_{2}$ precipitate (eq. 1) is dissolved in basic solution, forming zincate ions, $\mathrm{Zn}(\mathrm{OH})_{4}{ }^{2-}$ (eq. 2). Under hydrothermal conditions, $\mathrm{Zn}(\mathrm{OH})_{4}{ }^{2-}$ precipitates in the form of zinc oxide, $\mathrm{ZnO}$, and microrods are formed (eq. 3).

During precipitation, some $\mathrm{ZnO}$ clusters were formed on the microrod array layer, which can be attributed to the formation of aggregated $\mathrm{ZnO}$ nuclei in an initial homogeneous nucleation process. ${ }^{27,}{ }^{28}$ At the initial growth stage of the clusters, a large number of $\mathrm{ZnO}$ growth units resulted in a burst in homogeneous nucleation and formed aggregated $\mathrm{ZnO}$ nuclei. $\mathrm{ZnO}$ crystals at the initial growth stage exhibited many crystalline grains and boundaries, and had more defects than other regions and were not thermodynamically stable. Each grain of the initial $\mathrm{ZnO}$ crystals grew primarily along one growth direction, and Secondary growth from the defects occurred because of the large number of growth units. Moreover, the crystal surfaces with the defects further decreased their energy through surface reconstruction, providing the active sites for secondary nucleation. Therefore, $\mathrm{ZnO}$ clusters were formed on the microrod array layer. ${ }^{27}$

The twinned zinc oxide structures are often found as a type of nanostructures grown by liquid methods and it can be attributed to the linkage of single microrods throughout crystallization process. Wang et al. reported the twinned $\mathrm{ZnO}$ structures where $\mathrm{K}^{+}$or $\mathrm{Na}^{+}$ions acted as a bridge between the structural $\mathrm{ZnO}_{4}{ }^{6-}$ units. ${ }^{29}$ In our experiments, under hydrothermal conditions, abundant $\mathrm{Zn}(\mathrm{OH})_{4}{ }^{2-}$ units were formed, while $\mathrm{C}_{6} \mathrm{H}_{12} \mathrm{~N}_{4}$ in the solutions was hydrolyzed, which resulted in the complex $\left(\mathrm{CH}_{2}\right)_{6} \mathrm{~N}_{4}-4 \mathrm{H}^{+}$, as described by Equation (4): ${ }^{30}$

$$
\mathrm{C}_{6} \mathrm{H}_{12} \mathrm{~N}_{4}+4 \mathrm{H}_{2} \mathrm{O}=\left(\mathrm{CH}_{2}\right)_{6} \mathrm{~N}_{4}-4 \mathrm{H}^{+}+4 \mathrm{OH}^{-}
$$

When $\mathrm{Zn}(\mathrm{OH})_{4}{ }^{2-}$ ions were adsorbed by the complex $\left(\mathrm{CH}_{2}\right)_{6} \mathrm{~N}_{4}-4 \mathrm{H}^{+}$, the nuclei for twinning crystals were formed. By extending the reaction time, the twinned $\mathrm{ZnO}$ structures were developed.

The crystal structure and chemical composition of the typical zinc oxide microrod was determined by X-ray diffraction (XRD) and energy dispersive $\mathrm{x}$-ray spectrometry (EDS). In the XRD pattern (Fig. 5), all detected peaks are unambiguously assigned to the $\mathrm{ZnO}$ wurtzite phase as marked in XRD pattern (JCPDS 036-1451). Furthermore, no other peaks of any impurities were observed, indicating the high purity of the zinc oxide. In EDS spectrum of microrods of $\mathrm{ZnO}$ microrods, only $\mathrm{Zn}$ and $\mathrm{O}$ peaks were observed, demonstrating nearly stoichiometric ratio. The contents of $\mathrm{O}$ and $\mathrm{Zn}$ were 52.9 at. \% and 47.1 at. \%, respectively, and the ratio of O/Zn was $\sim 1.12$. Such EDS results further confirmed the formation of pure $\mathrm{ZnO}$ phase.

Photoluminescence (PL), as a powerful and non-destructive technique, has been widely used to investigate

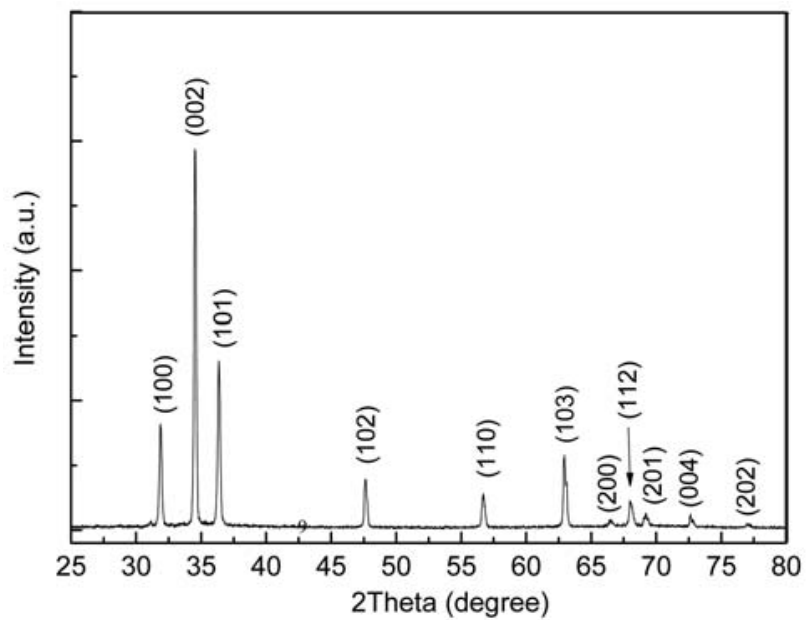

Fig. 5. XRD pattern of typical $\mathrm{ZnO}$ microrods.
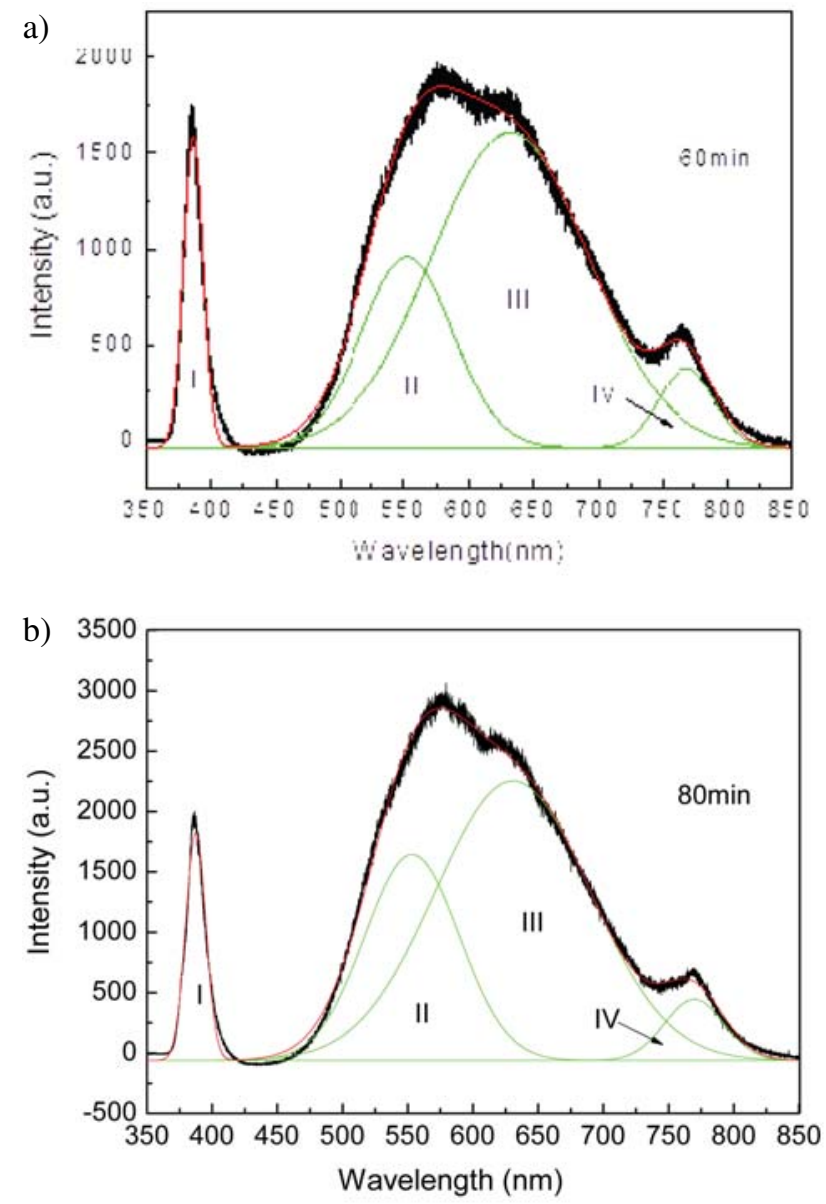

Fig. 6. The PL spectra of the $\mathrm{ZnO}$ microrods fabricated with various growth times: a) $60 \mathrm{~min}$; b) $80 \mathrm{~min}$. The spectra were deconvoluted by four parts, marked as UV band (I), green band (II), orange band (III), and NIR band (IV).

optical properties and the defects of various $\mathrm{ZnO}$ materials (bulk, films and nanorods, nanowires and nanotubes). ${ }^{31-35}$ Fig.6 shows the PL spectra of $\mathrm{ZnO}$ microrods 
grown through different times. The spectra were deconvoluted in four parts, marked as: UV band (I), green band (II), orange band (III), and near infrared (NIR) band (IV) by Gaussian fitting. An ultraviolet and a broad visible emissions were detected for both samples. The UV emission band demonstrated its maximum at $3.22 \mathrm{eV}(\sim 385$ $\mathrm{nm}$ ) with a full width at a half-maximum (FWHM) of $125 \mathrm{meV}$ and it could be attributed to the near-band edge emission of wide band gap of $\mathrm{ZnO}$. Generally, the broad visible emissions are related to the deep-level defects, such as the vacancies and interstitials of oxygen and zinc. ${ }^{36}$ To obtain more information on such defects, Gaussian fitting was carried out for the PL spectra of Zn$\mathrm{O}$ microrods. In visible range, the PL peaks at $\sim 550$ (green) and $630 \mathrm{~nm}$ (orange) were resolved, as shown in Fig. 6. These emissions could be considered to correspond with oxygen vacancies and interstitials in $\mathrm{ZnO}$ microrods, respectively. ${ }^{37} \mathrm{We}$ also noted NIR luminescence at about $775 \mathrm{~nm}$ in PL spectra. It was due to the secondorder diffraction of the UV luminescence.

The UV-visible spectra of $\mathrm{ZnO}$ microrods on graphene $/ \mathrm{SiO}_{2} / \mathrm{Si}$ with different growth times are shown in
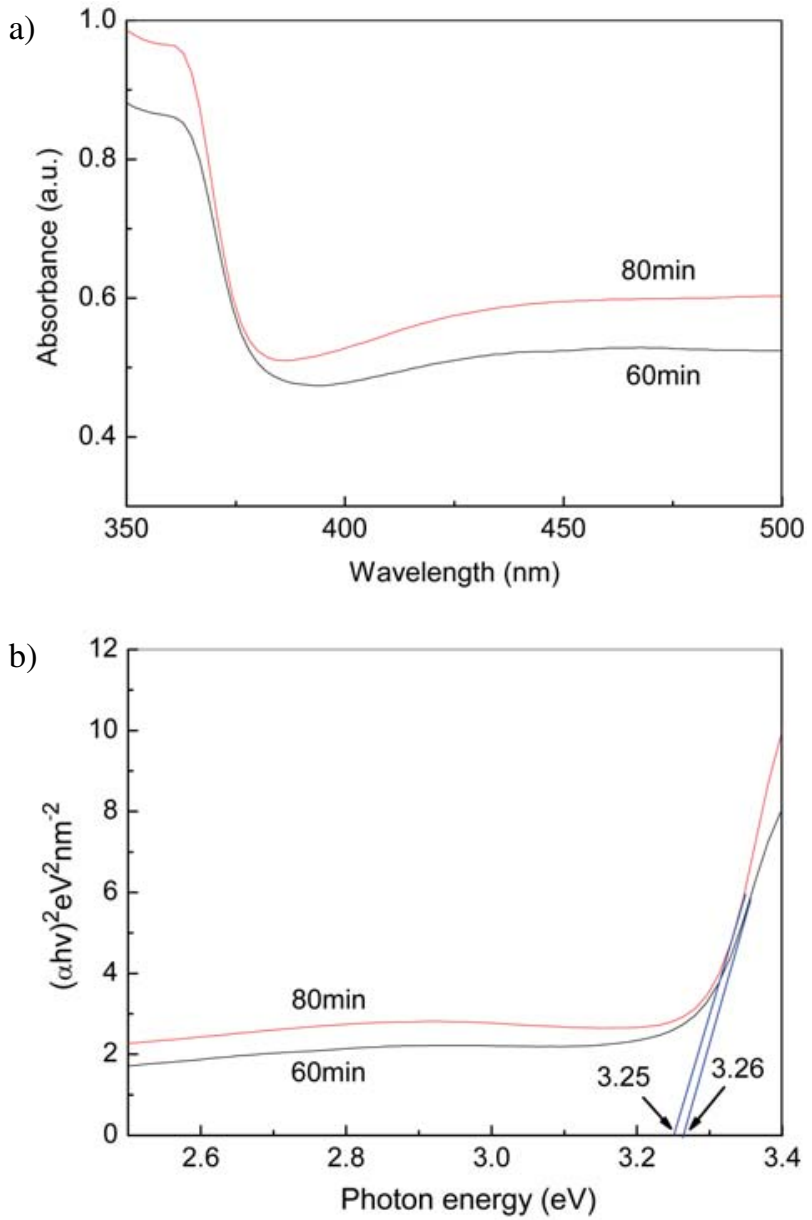

Fig. 7. UV-visible spectra of $\mathrm{ZnO}$ microrods grown with various growth time (a) and the corresponding band gap calculation (b).
Fig.7. They exhibited the fundamental absorption edge with the maximum absorption peak at $360 \mathrm{~nm}$. Such absorption edge corresponds to the electron excitation from valance to conduction band, determining the band gap of semiconductor. For $\mathrm{ZnO}$ microrods in these experiments, the band gap was evaluated to be $\sim 3.25 \mathrm{eV}$ by the equation $(\mathrm{I}):^{38-40}$

$$
(\alpha h v)^{2}=\mathrm{D}\left(\mathrm{hv}-\mathrm{E}_{\mathrm{g}}\right)
$$

where $\mathrm{h} v$ is the photon energy, $\mathrm{E}_{\mathrm{g}}$ is the optical band gap, and $\mathrm{D}$ is a constant. $\alpha$ is absorbance. Fig. $7 \mathrm{~b}$ demonstrates the relationship between $(\alpha h v)^{2}$ and hv which enables the calculation of the aforementioned band gap.

The photocatalytic activities of zinc oxide microrods on graphene/ $/ \mathrm{SiO}_{2} / \mathrm{Si}$ is shown in Fig.8. It can be seen that the absorption intensity at $\sim 550 \mathrm{~nm}$ of aqueous Rhodamine $\mathrm{B}(\mathrm{RhB})$ solution decreased gradually with the irradiation time, suggesting the successful degradation by the $\mathrm{ZnO}$ microrods. After $3 \mathrm{~h}$ irradiation period, the degradation efficiency was $\sim 65 \%$, indicating the effective photocatalysis. To confirm their photocatalytic activity, aque-
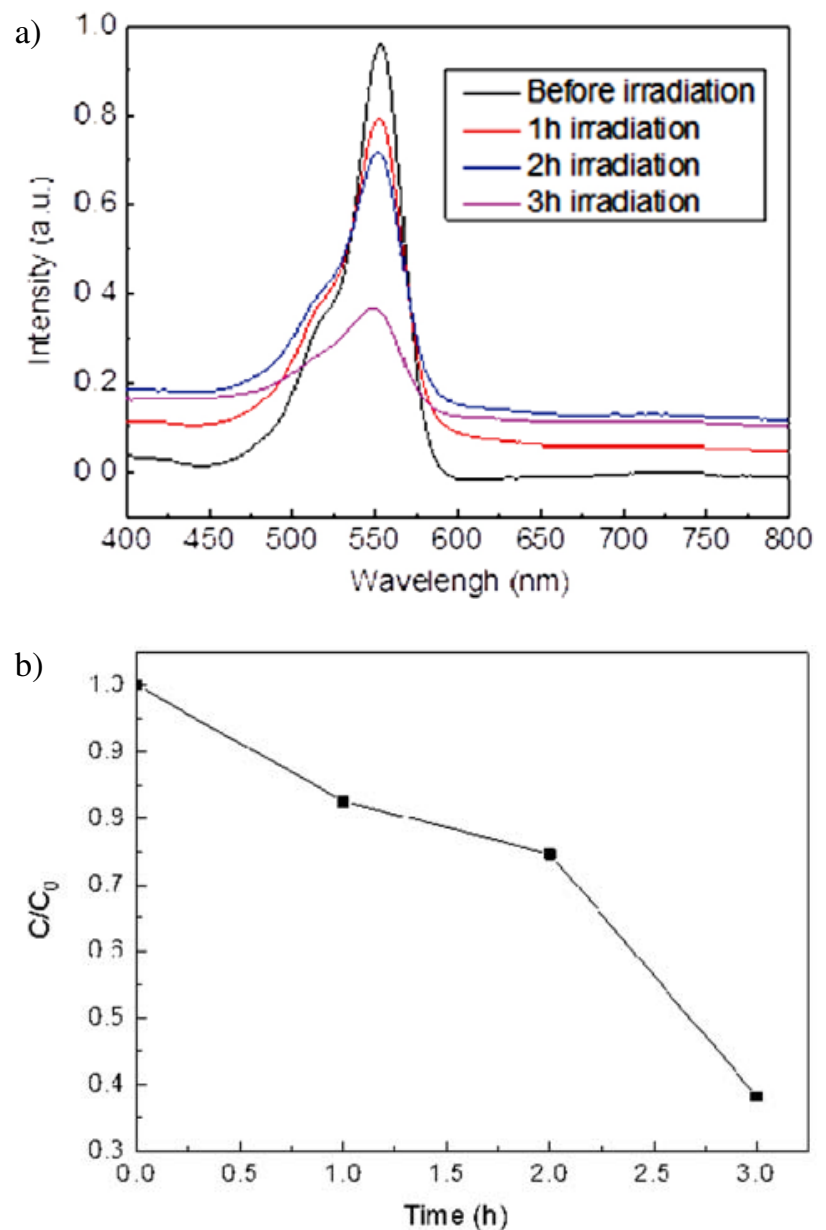

Fig.8. (a) Degradation of Rhodamine B with different irradiation times. (b) Degradation rate of Rhodamine $\mathrm{B}$ with $\mathrm{ZnO}$ microrods. 
ous $\mathrm{RhB}$ solution without $\mathrm{ZnO}$ micorods was also irradiated by UV light. However, even after $4 \mathrm{~h}$ irradiation, no obvious changes were observed in the absorption intensity. Therefore, the measured degradation of $\mathrm{RhB}$ in solution originated from $\mathrm{ZnO}$ micorods immersed in it. Their photocatalytic activity could be assigned to oxygen vacancies and oxygen interstitials. These two oxygen defects serve as the active sites of the zinc oxide photocatalytic performance. ${ }^{41-43}$

Previously described PL results have indicated that there were abundant oxygen vacancies and interstitials within the structure of $\mathrm{ZnO}$ microrods, which offered enough active sites for their photocatalytic activity. Besides that, the band gap of $\mathrm{ZnO}$ microrods $(\sim 3.25 \mathrm{eV})$ is smaller than that of bulk $\mathrm{ZnO}(3.37 \mathrm{eV})$, and, therefore, it is easier to form the photoinduced electrons and holes under the irradiation. In addition, the synergy of surface oxygen defects and graphene hybridization could also enhance the overall catalytic performances. ${ }^{44}$ Consequently, $\mathrm{ZnO}$ microrods on graphene $/ \mathrm{SiO}_{2} / \mathrm{Si}$ demonstrate good photocatalytic properties, which shows the potential of their use in wastewater treatment applications.

\section{Conclusions}

$\mathrm{ZnO}$ microrods were grown on the graphene/ $\mathrm{SiO}_{2} / \mathrm{Si}$ by hydrothermal method. The XRD pattern and EDS spectrum demonstrated that these microrods are of pure wurtzite phase. The SEM pictures showed that some $\mathrm{ZnO}$ clusters and twinned structures were formed on the microrod array layer. The formation of such clusters is considered to be due to the aggregation of oxide nuclei during the growth process, and the twinned structures were attributed to the linkage of the growing crystals by $\mathrm{C}_{6} \mathrm{H}_{12} \mathrm{~N}_{4}$. Photoluminescence spectra revealed the abundant $\mathrm{O}$ defects $\left(\mathrm{V}_{\mathrm{O}}\right.$ and $\left.\mathrm{O}_{\mathrm{i}}\right)$ in $\mathrm{ZnO}$ microrods. Furthermore, hydrothermally formed microrods on graphene $/ \mathrm{SiO}_{2} / \mathrm{Si}$ exhibited good photocatalytic performance with oxygen vacancies and interstitials being the active sites of the $\mathrm{ZnO}$ photocatalyst. These results indicate a potential of zinc oxide microrods in the wastewater treatment applications.

\section{Acknowledgements}

The work is supported by NEWFELPRO in Croatia (Grant Agreement No.13) and the Talent Plan at Anhui University of Technology in China. H.H thanks the Natural Science Foundation of Jiangsu Higher Education Institutions of China (Grant NO. 14KJB140005). Financial support by the Croatian Center of Excellence for Advanced Materials and Sensing Devices is gratefully acknowledged.

\section{References}

1. K. S. Novoselov, A. K. Geim, S. V. Morozov, D. Jiang, Y. Zhang, S. V. Dubonos, V. Grigorieva and A. A. Firsov, Science 2004, 306, 666-669.

http://dx.doi.org/10.1126/science.1102896

2. F. Scarpal, S. Adhikari, A. S. Phani, Nanotechnology 2009 , 20, 065709.

http://dx.doi.org/10.1088/0957-4484/20/6/065709

3. H.Y. Mao, Y. H. Lu, J. D. Lin, S. Zhong, A.T.S. Wee, W. Chen, Prog. Surf. Sci. 2013, 88, 132-159.

http://dx.doi.org/10.1016/j.progsurf.2013.02.001

4. X. F. Xu, L. F. C. Pereira, Y. Wng, J. Wu, K. W. Zhang, X. M. Zhao, S. Bae, C. T. Bui, R. G. Xie, J. T. L. Thong, B. H. Hong, K. P. Loh, D. Donadio, B. W. Li, B. Özyilmaz, Nature Commun. 2014, 5, 3689.

5. F. Bonaccorso, Z. Sun, T. Hasan, A. C. Ferrari, Nature Photon. 2010, 4, 611-622. http://dx.doi.org/10.1038/nphoton.2010.186

6. M. C. Lemme, T. J. Echtermeyer, M. Baus and H. Kurz, IEEE Electr. Device Lett. 2007, 28, 282-284. http://dx.doi.org/10.1109/LED.2007.891668

7. Q. L. Bao, K. P. Loh, ACS Nano 2012, 6, 3677-3694. http://dx.doi.org/10.1021/nn300989g

8. K. Chung, H. Beak, Y. Tchoe, H. Oh, H. Yoo, M. Kim, G.-C. Yi, APL Mat. 2014, 2, 092512. http://dx.doi.org/10.1063/1.4894780

9. A. M. Munshi, D. L. Dheeraj, V. T. Fauske, D.-C. Kim, A. T. J. van Helvoort, B.-O. Fimland, H. Weman, Nano Lett. 2012, 12, 4570-4576. http://dx.doi.org/10.1021/nl3018115

10. P. K. Mohseni, A. Behnam, J. D. Wood, C. D. English, J. W. Lyding, E. Pop, X. L. Li, Nano Lett. 2013, 13, 1153-1161. http://dx.doi.org/10.1021/nl304569d

11. J. Yi , J. M. Lee, W. II Park, Sensor Actuat. B-Chem. 2011, 155, 264-269.

12. W. II Park, C.-H. Lee, J. M. Li, N.-J. Kim, G.-C. Yi, Nanoscale 2011, 3, 3522-3533.

13. H. Park, S. Chang, Jean, J. J. Cheng, P. T. Araujo, M. S. Wang, M. G. Bawendi, M. S. Dresselhaus, V. Bulović, J. Kong, S. Gradečak, Nano Lett. 2013, 13, 233-239. http://dx.doi.org/10.1021/nl303920b

14. C.-H. Hsu. C.-C. Lai, L.-C. Chen, P.-S. Chan, J. Nanomater. 2014, 2014, 748319.

15. M. Dutta, S. Sarkar, T. Ghosh, D. Basak, J. Phys. Chem. C 2012, 116, 20127-20131. http://dx.doi.org/10.1021/jp302992k

16. Y.-J. Kim, J.-H. Lee, G.-C.Yi, Appl. Phys. Lett. 2000, 95, 213101. http://dx.doi.org/10.1063/1.3266836

17. C. Xu, B.-S. Kim, J.-H. Lee, M. Kim, S.W. Hwang, B. L. Choi, E. K. Lee, J. M. Kim, D. Whang, Mater. Lett. 2012, 72, 25-28. http://dx.doi.org/10.1016/j.matlet.2011.12.057

18. N. S. A. Aziz, T. Nishiyama, N. I. Rusli, M. R. Mahmood, K. Yasui, A. M. Hashim, Nanoscale Res. Lett. 2014, 9, 337. http://dx.doi.org/10.1186/1556-276X-9-337

19. Y.-J. Kim, Hadiyawarman, A. Yoon, M. Kim, G.-C. Yi, C.

Fan et al.: The Fabrication of ZnO Microrods on Monolayer ... 
Liu, Nanotechnology 2011, 22, 245603. http://dx.doi.org/10.1088/0957-4484/22/24/245603

20. J. O. Hwang, D. H. Lee, J. Y. Kim, T. H. Han, B. H. Kim, M. Park, K. No, S. O. Kim, J. Mater. Chem. 2011, 21, 34323437. http://dx.doi.org/10.1039/C0JM01495H

21. J. M. Lee, Y. B. Pyun, J. Yi, J. W. Choung, W. I Park, J. Phys. Chem. C 2009, 113, 19134-19138. http://dx.doi.org/10.1021/jp9078713

22. J. C. Fan, T. F. Li, Y. H. Gao, J. G. Wang, H. L. Ding, H. Heng, J. Mater. Sci.- Mater. Electron. 2014, 25, 4333-4338. http://dx.doi.org/10.1007/s10854-014-2170-1

23. A. C. Ferrari, D. M. Basko, Nature Nanotechnol. 2013, 8, 235-246. http://dx.doi.org/10.1038/nnano.2013.46

24. Y. J. Sun, L. Wang, X. G. Yu and K. Z. Chen, Cryst Eng Commun. 2012, 14, 3199-3204. http://dx.doi.org/10.1039/c2ce06335b

25. P. Li, H. Liu, B. Lu, Y. Wei, J. Phys. Chem. C 2010, 114, 21132-21137. http://dx.doi.org/10.1021/jp107471u

26. S. W. Sun, I. A. Mudunkotuwa, T. Rupasinghe, V. H. Grassian, Langmuir 2011, 27, 6059-6068. http://dx.doi.org/10.1021/la200570n

27. Z. Z. Han, L. Liao, Y. T. Wu, H. B. Pan, S. F. Shen, J. Z. Chen, J. Hazard. Mater. 2012, 217-218, 100-106. http://dx.doi.org/10.1016/j.jhazmat.2012.02.074

28. F. Solís-Pomar, E. Martínez, M.F. Meléndrez, E. Pérez-Tijerina, Nanoscale Res. Lett. 2011, 6, 524. http://dx.doi.org/10.1186/1556-276X-6-524

29. B. G. Wang, E. W. Shi, W. Z. Zhong, Cryst. Res. Technol. 1998, 33, 937-941.

http://dx.doi.org/10.1002/(SICI)1521-4079(1998)33:6 $<937:$ :AID-CRAT937>3.0.CO;2-8

30. Z. Q. Hou, Y. X. Wang, L. H. Shen, H. Guo, G. X. Wang, Y. Li, S. F. Zhou, Q. Q. Zhang, Q. Jiang, Nanoscale Res. Lett. 2012, 7, 507. http://dx.doi.org/10.1186/1556-276X-7-507

31. D. W. Hamby, D. A. Lucca, M. J. Klopfstein, G.Cantwell, J.
Appl. Phys. 2003, 93, 3214. http://dx.doi.org/10.1063/1.1545157

32. X. M. Teng, H. T. Fan, S. S. Pan, C, Ye, G. H. Li, J. Phys. D: Appl. Phys. 2006, 39, 471-476. http://dx.doi.org/10.1088/0022-3727/39/3/008

33. C. Chen, H. P. He, Y. F. Lu, K. W. Wu, Z. Z. Ye, ACS Appl. Mater. Interfaces, 2013, 5, 6354-6359. http://dx.doi.org/10.1021/am401418b

34. G. D. Yuan, W. J. Zhang, J. S. Jie, X. Fan, J. A. Zapien, Y. H. Leung, L. B. Luo, P. F. Wang, C. S. Lee, S. T. Lee, Nano Lett. 2008, 8, 2591-2597. http://dx.doi.org/10.1021/nl073022t

35. C.C. Wu, D.S. Wuu, P. R. Lin, T.N. Chen, R.H. Hong, Crys.Growth \& Des. 2009, 9, 4555-4561. http://dx.doi.org/10.1021/cg900557n

36. A. van Dijken, E. A. Meulenkamp, D. Vanmaekelbergh, A. Meijerink, J. Phys. Chem. B 2000, 104, 1715. http://dx.doi.org/10.1021/jp993327z

37. A. Janotti, C. G. Van de Walle, Appl. Phys. Lett. 2005, 87, 122102. http://dx.doi.org/10.1063/1.2053360

38. J. Tauc, Amorphous and Liquid Semiconductors, London: Plenum, 1974. http://dx.doi.org/10.1007/978-1-4615-8705-7

39. S. T. Tan, B. J. Chen, X. W. Sun, W. J. Fan, H. S. Kwok, X. H. Zhang, S. J. Chua, J. Appl. Phys. 2005, 98, 013505. http://dx.doi.org/10.1063/1.1940137

40. E. A. David, N. F. Mott, Philos. Mag.1970, 22, 903-922. http://dx.doi.org/10.1080/14786437008221061

41. S. Horikoshi, A. Saitou, H. Hidaka, N. Serpone, Environ. Sci. Technol. 2003, 37, 5813-5822. http://dx.doi.org/10.1021/es030326i

42. X. P. Lin, T. Huang, F. Q. Huang, W. D. Wang, J. L. Shi, J. Phys. Chem. B 2006, 110, 24629-24634. http://dx.doi.org/10.1021/jp065373m

43. J. C. Wang, P. Liu, X. Z. Fu, Z. H. Li, W. Han, X. X. Wang, Langmuir 2009, 25, 1218-1223. http://dx.doi.org/10.1021/la803370z

44. X. J. Bai, L. Wang, R. L. Zong, Y. H. Lv, Y. Q. Sun, Y. F. Zhu, Langmuir 2013, 29, 3097-3105. http://dx.doi.org/10.1021/la4001768

\section{Povzetek}

$\mathrm{S}$ preprosto hidrotermalno sintezo smo na substratu grafen $/ \mathrm{SiO}_{2} / \mathrm{Si}$ pripravili palčke cinkovega oksida $(\mathrm{ZnO})$ mikronskih velikosti. Dobljeni produkt smo karakterizirali z rentgensko praškovno difrakcijo, vrstično elektronsko mikroskopijo, energijsko disperzijsko rentgensko spektrometrijo, fotoluminiscenco in UV-VIS spektrometrijo. Palčke ZnO imajo heksagonalno wurtzitno strukturo. Na plasti iz urejenih palčk smo opazili tudi nekaj klastrov in dvojčkov ZnO. V članku razpravljamo o mehanizmu tvorbe plasti ZnO iz podolgovatih zrn, s poudarkom na mehanizmu nastajanja klastrov in dvojčkov $\mathrm{ZnO}$. Poleg tega so palčke $\mathrm{ZnO}$ pokazale dobro fotokatalitsko aktivnost pri procesu razgradnje rodamina $\mathrm{B}$, kar velja pripisati kisikovim prazninam in intersticijskim mestom, ki delujejo kot fotokatalitska aktivna mesta. 